\title{
What determines the growth of tropical reef fish larvae in the plankton: food or temperature?
}

\author{
M. G. Meekan ${ }^{1, *}$, J. H. Carleton ${ }^{2}$, A. D. McKinnon ${ }^{2}$, K. Flynn ${ }^{3}$, M. Furnas ${ }^{2}$ \\ ${ }^{1}$ Australian Institute of Marine Science, Building 42, Northern Territory University, Darwin, Northern Territory 0909, Australia \\ ${ }^{2}$ Australian Institute of Marine Science, P.M.B. 3, Townsville MC, Queensland 4810, Australia \\ ${ }^{3}$ Long Island University, Southampton College, 239 Montauk Highway, Southampton, New York 11968-4198, USA
}

\begin{abstract}
The late-stage larvae of the reef fish Pomacentrus coelestis were collected using light traps at stations on a cross-shelf transect near Northwest Cape, Western Australia, during the spring and summer months (October to February) of 1997-98 and 1998-99. Physical (water temperature, wind) and biological (chlorophyll $a$, zooplankton abundance) variables were measured concurrently at each station. In 1997-98, environmental conditions were characterised by intrusive upwelling onto the shelf, relatively cooler water temperatures and higher chlorophyll $a$ and zooplankton biomass. During the 1998-99 summer, water temperatures were warmer, and chlorophyll $a$ and zooplankton biomass were relatively low. Catches of $P$. coelestis were much lower in the first summer (197 fish) than the second (1483 fish). Records of planktonic growth were obtained from otoliths of subsets of larvae from both summers. Growth varied among months within each summer; however, on average, larvae grew more slowly in the 1997-98 summer than the $1998-99$ summer $\left(0.48 \mathrm{~mm} \mathrm{~d}^{-1}\right.$ vs $0.53 \mathrm{~mm}$ $\mathrm{d}^{-1}$ respectively), despite the presumed food (copepods) being more abundant in the plankton. Partial correlation analysis showed that water temperature explained approximately $30 \%$ of the variation in growth of larval $P$. coelestis. In contrast, chlorophyll $a$ and zooplankton abundance explained much less (4.1 and $3.5 \%$, respectively).
\end{abstract}

KEY WORDS: Larval fish · Growth · Otoliths · Food · Copepods · Zooplankton · Temperature

\section{INTRODUCTION}

The mortality suffered by the planktonic eggs and larvae of marine fishes is thought to be strongly influenced by growth rate, such that fast-growing fish have higher rates of survivorship than slow-growing fish of the same age (Anderson 1988, Bailey \& Houde 1989). High rates of mortality, in combination with the great abundance of egg and early larval stages, mean that small changes in growth rates in the plankton can lead to very large fluctuations in the numbers of fish becoming juveniles and adults (Houde 1989, Cushing \& Horwood 1994). For this reason, larval growth and survivorship are central topics in fisheries research.

Food supply and water temperature are believed to be the primary environmental determinants of marine fish larvae growth rates (Heath 1992, Houde \& Zastrow 1993). Generally, the influence of food has received more attention than temperature (Blaxter 1992, Heath 1992). The reasons for this are partly historical, in that the importance of food quality and quantity to the growth and survivorship of larvae was recognised by Hjort (1914) early last century, while studies of the effects of temperature have a more recent origin (Houde 1989, Blaxter 1992).

In the warm waters of the tropics, larval fish have relatively fast growth rates that require high rates of food intake (Houde 1989, Houde \& Zastrow 1993). Additionally, tropical fish larvae inhabit an environment where seasonal cycles of temperature are damped in comparison to temperate regions. Under such conditions, food supply should be the primary determinant of growth rate variability (Houde 1989). At present, little evidence exists to determine if this is the case. While a number of recent studies have observed differences in growth rates among cohorts of 
larval coral reef fishes (Wellington \& Victor 1992, McCormick \& Molony 1995, Searcy \& Sponaugle 2000, Wilson \& Meekan 2002), none of these concurrently examined the feeding environments that were experienced by larvae. In one study, water temperature was found to explain up to $30 \%$ of the variability in planktonic growth rates of the tropical goatfish Upeneus tragula over a 2 mo period (McCormick \& Molony 1995). However, the extent to which temperature and food availability were correlated during this time was unknown.

Summer upwelling events, in combination with tides and internal waves, episodically intrude cool, nutrient-rich waters onto the southern North West (NW) Shelf of tropical Western Australia (Holloway et al. 1985). These events trigger short-term pulses of elevated primary production (M. Furnas unpubl.). Though the copepod community of the area acts as a 'weak link/strong filter' (sensu Runge 1998) between primary production and higher trophic levels, in upwelling years there is an accumulation of zooplankton biomass potentially available as food for fish larvae (McKinnon \& Duggan 2001). In years not characterised by upwelling, zooplankton biomass is lower, and water temperatures higher (McKinnon \& Duggan 2001). These contrasting environments provide an opportunity to examine the relative importance of food and temperature to the planktonic growth and survival of the larvae of tropical reef fishes. If food availability is the primary factor regulating growth of larvae, then growth rates should be greatest during years of stronger upwelling, when conditions on the NW Shelf favour the production of food resources. Alternatively, if temperature is the principal factor driving larval fish growth, then growth rates should be highest during years of lower upwelling and productivity when surface waters are warmer.

We tested these predictions on the southern NW Shelf during 2 summer recruitment seasons for reef fishes. The first of these summers (1997-98) was characterised by El Niño/Southern Oscillation conditions that contributed to lower water temperatures and enhanced regional productivity, while La Niña conditions and well developed stratification of the water column with warmer temperatures, and lower regional productivity typified the second summer (M. Furnas unpubl.). The subject of the study was the damselfish Pomacentrus coelestis. Damselfish show variation in larval growth rates at both regional (1000s of km, Thorrold \& Milicich 1990, Wellington \& Victor 1992) and local (10s of km, Wilson \& Meekan 2002) scales. P. coelestis has a very broad distribution, occurring from cool, subtropical waters to equatorial regions throughout the Indo-Pacific (Allen 1991). P. coelestis larvae are thus capable of tolerating a broad range of environ- mental conditions while in the plankton. Adults are abundant on coral reefs of the NW Shelf (M. G. Meekan \& A. Halford unpubl.). We used otolith analysis to examine age and growth of larvae collected just prior to settlement in each of the 2 summers. These traits were compared with concurrent estimates of chlorophyll a concentrations, zooplankton abundance and patterns of larval supply.

\section{MATERIALS AND METHODS}

Field study. Data were collected on a series of 5 cruises of $10 \mathrm{~d}$ duration centred around successive new moons in the spring and summer months (October to February) of 1997-98 and 1998-99. All sampling was conducted at stations along a cross-shelf transect extending from the inner shelf (Stn A, $15 \mathrm{~m}$ water depth, Fig. 1) to the outer continental slope (Stn $\mathrm{H}$, $750 \mathrm{~m}$ water depth, Fig. 1).

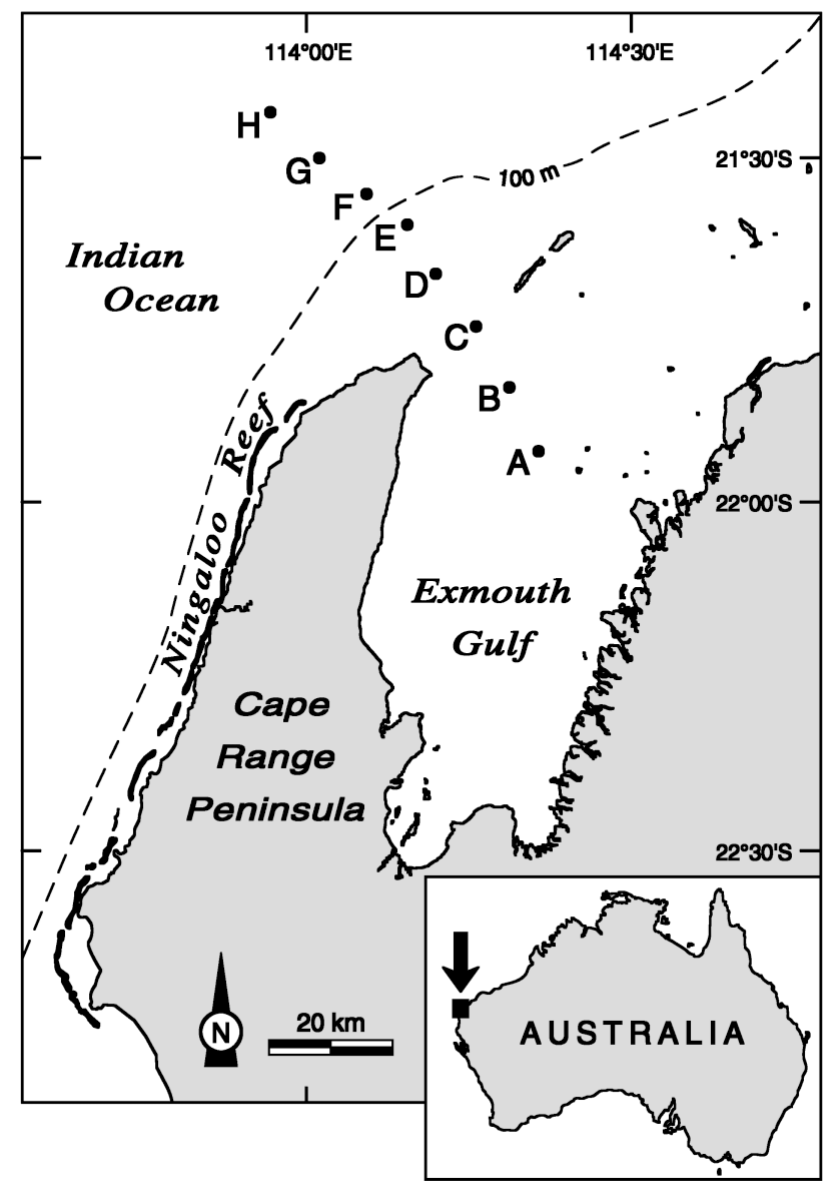

Fig. 1. Location map of study area showing stations (A to $\mathrm{H}$ ) on cross-shelf transect in Exmouth Gulf, NW Shelf 
Environmental variables, chlorophyll $a$ and zooplankton biomass. Wind speed and direction were measured by a weather station located at Milyering on the west coast of the Cape Range Peninsula. At each light trap station, a CTD equipped with a fluorometer was deployed to within a few metres of the bottom to determine water temperature, salinity and chlorophyll a concentration. The fluorometer was calibrated against bottle casts collected during each cruise. Vertical zooplankton hauls (to a maximum depth of $60 \mathrm{~m}$ ) were collected with a $0.5 \mathrm{~m}$ diameter, modified WP-2 net of $73 \mu \mathrm{m}$ mesh fitted with a flowmeter. Each net sample was split in half using a Folsom plankton splitter. One half was filtered onto a preweighed $73 \mu \mathrm{m}$ mesh disk and frozen, while the other was preserved in formalin. In the laboratory, the frozen filter was dried and re-weighed to estimate zooplankton biomass (mg dry wt $\mathrm{m}^{-3}$ ), while the preserved sample was identified to provide an estimate of community composition and abundance of zooplankton.

Larval fish. Late stage larval fish were captured using light traps (Doherty 1987). This method selectively targets photopositive fishes in the days just prior to their settlement on reefs (Meekan et al. 1993). The design of the traps is shown in Meekan et al. (2001). Four traps were deployed at each station. Two traps were suspended from buoys at the surface so that their entrance slits were at approximately $1 \mathrm{~m}$ depth, while the second pair of traps fished $3 \mathrm{~m}$ off the bottom at shallower stations and at a maximum of $75 \mathrm{~m}$ depth at offshore stations. The surface floats of the deep light traps were tethered to the surface traps. Up to 4 inshore (Stns A-D) or offshore (Stns E-H) stations were sampled each night. Traps were released from the vessel and allowed to drift with the current for $1 \mathrm{~h}$, after which time they were retrieved. Catches were washed from the traps and immediately preserved in $100 \%$ ethanol.

Otolith analysis. Otoliths from 75 Pomacentrus coelestis collected by light traps in each of the summers were analysed. The fish were selected in proportion to the numbers collected on each cruise and their distribution in $1 \mathrm{~mm}$ size classes of standard length (SL) within each cruise. Lapillae were dissected from each fish and cleaned of adhering tissue. One of the pair of lapillae was mounted over the edge of a glass slide using thermoplastic glue and the protruding portion ground off on lapping film. The glue was then heated and the otolith reorientated so that it sat upright on the cut edge in the centre of the slide. The upright portion of the otolith was then ground on lapping film to produce a thin transverse section that contained the nucleus. Sections were viewed under immersion oil with a compound microscope using transmitted light at $1000 \times$ magnification. An image analysis system (OPTI-
MAS) was used to measure the width of each increment from the nucleus along the longest axis of the otolith. It was assumed that the first increment closest to the nucleus of the otolith was formed at the time of hatching (Campana \& Neilson 1985, Wellington \& Victor 1989).

Data analysis. Differences in temperature, chlorophyll a concentrations, zooplankton biomass and the abundance of total zooplankton, copepods and Pomacentrus coelestis were compared by 3-way, fixedfactor analysis of variance (ANOVA). For P. coelestis factors included year (1997-98, 1998-99), month (November to February) and station (B to E). These included those months when, and stations where, $P$. coelestis was present in catches. For the remaining variables, factors included year (1997-98, 1998-99), season (spring-October and November; summerDecember, January and February) and station (A to H). Prior to analysis, data were tested for heteroscedasticity by Cochran's procedure (Weiner 1971) and, where necessary, log-transformed to stabilise variance. It was also necessary to pool biological and physical data (excluding fish abundance) into seasons to conform with the assumptions of the analysis. For the variables differing significantly among factors, homogeneous subsets were extracted by Tukey's HSD test (Zar 1984). The critical probability level for significance testing was set at $5 \%$ for all statistical analyses.

Partial correlation analysis was used to examine the relationship between growth rates, represented by log-transformed daily increment widths, and temperature, chlorophyll $a$, log of zooplankton biomass and the log abundance of total zooplankton and copepods. Only daily growth rates of fish for which a complete set of physical and biological data was available were included in the analysis $(n=136)$.

Otolith radii and increment widths provided daily growth records of Pomacentrus coelestis in the plankton. Monthly and seasonal patterns in growth were analysed using repeated measures MANOVAs (Chambers \& Miller 1994). These analyses compared radii and increament widths of fish among cruises (November, December, January and February) and summers (1997-98 and 1998-99). As variance increased with age, radii data sets were natural log-transformed prior to analysis. Age at capture in light traps varied among individuals. Since a repeated measures MANOVA requires identical record lengths for all individuals in the analysis, we trimmed data sets to 1 to $17 \mathrm{~d}$ after hatching, the age of the youngest fish at capture. Wilks Lambda was used as the test statistic. Where there were significant results in the MANOVAs, univariate $F$-tests were used to identify days where there were significant differences in otolith radii and increment 
widths among cruises and summers. As differences among individuals were likely to be small, these analyses used otolith growth to avoid errors that are likely to be introduced by back-calculation of fish size from otoliths (Chambers \& Miller 1994).

\section{RESULTS}

\section{Environmental data and plankton standing stock}

Strong and consistent southwesterly (alongshore) wind was a consistent feature of El Niño-Southern Oscillation conditions in the 1997-98 summer. There was a strong diel variation in wind strength, with the strongest wind during the night. This wind pattern created suitable conditions for offshore Ekman transport of surface waters and the upwelling of cool, nutrient-rich water onto the shelf (M. Furnas unpubl.). In the 1998-99 summer, winds were more variable in both direction and strength. Upwelling-favourable wind conditions were less common, with the result that the water column on the continental slope was frequently stratified. Warm, nutrient-poor water was present on the shelf through most of the summer (M. Furnas unpubl.).

A multi-factorial ANOVA confirmed that average water temperatures in the upper $20 \mathrm{~m}$ of the water column at Stns A to $\mathrm{H}$ on the shelf were significantly higher in the second summer than the first. During both summers, water temperatures increased from late spring (October to November) to summer (December to February) (Fig. 2, Table 1).

Analysis of chlorophyll a data at Stns A to $\mathrm{H}$ resulted in significant interactions among factors. A posteriori tests (Tukey HSD for unequal sample sizes) were inconclusive. However, chlorophyll a concentrations tended to be greater at inshore Stns B, C and D during October and November and more uniform across the shelf from December to February (Fig. 2, Table 1).

On average, the biomass of zooplankton captured by the $73 \mu \mathrm{m}$ mesh plankton net was 3 times greater in the first summer of sampling than the second $174.59 \mathrm{mg}$ $\mathrm{m}^{-3}$ vs $26.77 \mathrm{mg} \mathrm{m}^{-3}$ ), with significantly higher standing stock in the summer of 1997-98 than all other year-season combinations (Fig. 2, Table 1). Strong cross-shelf patterns in zooplankton biomass were also evident, with higher biomass occurring at inshore Stns A, B and C than at offshore Stns F, G and H in both summers (Table 1).

Both total zooplankton and copepod abundance were significantly higher in the first year of sampling (Fig. 2, Table 1). However, only total zooplankton abundance showed a significant increase from spring to summer and a difference between inshore and offshore locations (Fig. 2, Table 1).
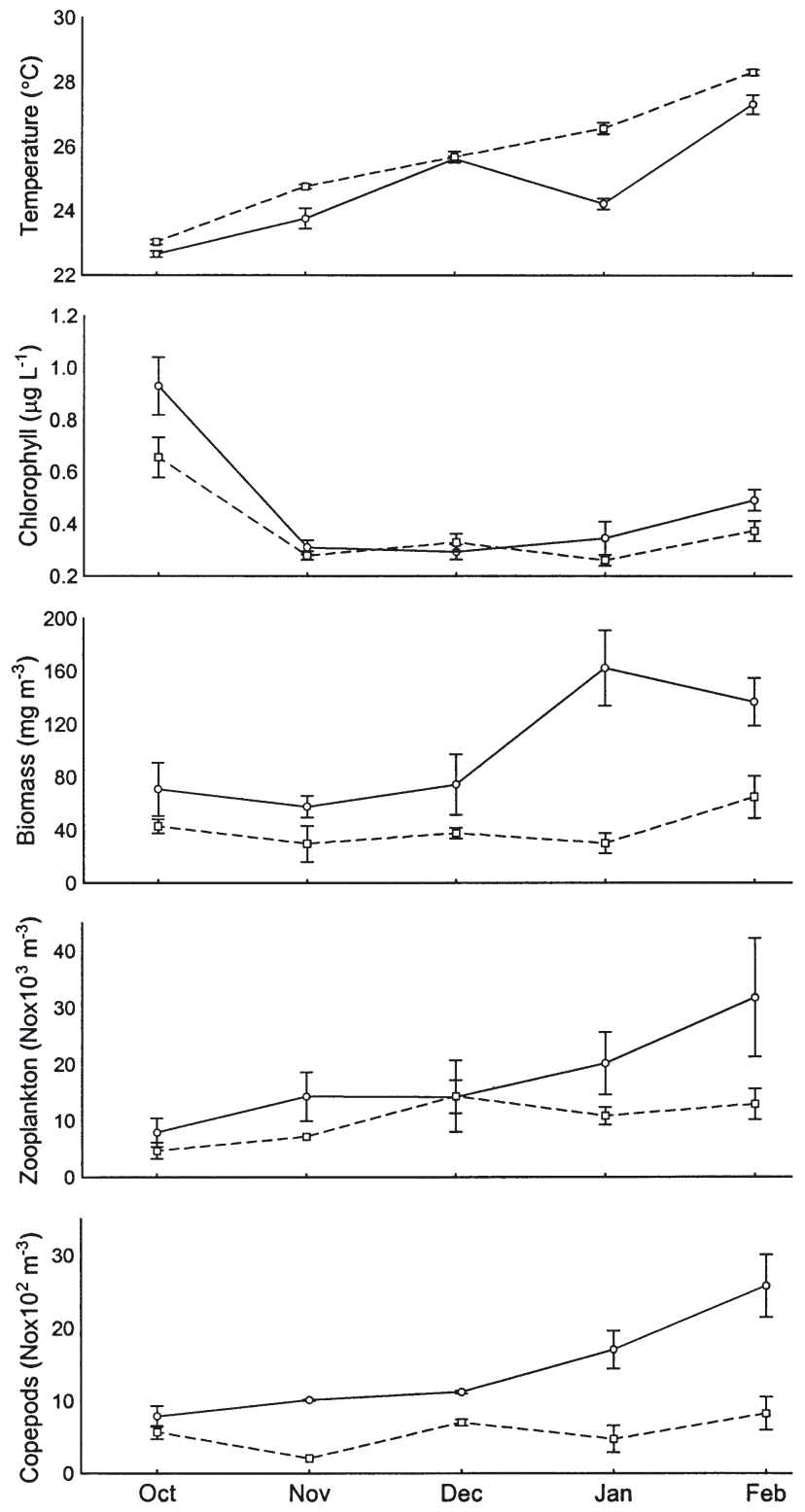

Fig. 2. Mean temperature, chlorophyll $a$, zooplankton biomass and abundance, copepod abundance $( \pm \mathrm{SE})$ at inshore stations (A to D) on a cross shelf transect in each of 2 summers (1997-98, solid line; and 1998-99, dotted line) on the NW Shelf

\section{Growth of larval fish}

Significantly fewer pre-settlement Pomacentrus Coelestis were collected by light traps in the first summer than in the second (197 vs 1483 ; Fig. 3, Table 1 ). The majority (95\%) of these fish were caught at Stns C and $\mathrm{D}$ at the edge of Exmouth Gulf.

The average size of fish collected by the traps $(15 \mathrm{~mm} \pm 0.9 \mathrm{SD})$ was similar in both summers (Kolmogorov-Smirnov [KS] test, $p>0.05$ ), although fish collected by the traps in the first summer tended to be 
Table 1 Summary of 3-way, fixed-factor ANOVAs. For Pomacentrus coelestis, factors included year (1997-98, 1998-99), month (November to February) and station (B to E). For the remaining variables, factors included year (1997-98, 1998-99), season (spring-October and November; summer-December, January and February) and station (A to H). Prior to analysis, data were tested for heteroscedasticity and, where necessary, log-transformed. For those variables differing significantly among factors, homogeneous subsets were extracted by Tukey's HSD test (Zar 1984) at $\mathrm{p}<0.05$

\begin{tabular}{|c|c|c|c|c|c|c|c|}
\hline Parameter & Factor & SS & $\mathrm{df}$ & MS & $F$ & $\mathrm{P}$ & Tukey`s HSD (unequal n) \\
\hline \multirow{8}{*}{$\begin{array}{l}\text { Temperature } \\
\left({ }^{\circ} \mathrm{C}\right)\end{array}$} & Year & 10.21 & 1 & 10.21 & 4.85 & 0.035 & \multirow{8}{*}{$\begin{array}{l}1998-99>1997-98 \\
\text { Summer }>\text { Spring }\end{array}$} \\
\hline & Season & 116.22 & 1 & 116.22 & 55.20 & $<0.001$ & \\
\hline & Station & 14.04 & 7 & 2.01 & 0.95 & 0.48 & \\
\hline & Year $\times$ Season & 5.84 & 1 & 5.84 & 2.77 & 0.11 & \\
\hline & Year $\times$ Station & 4.56 & 7 & 0.65 & 0.31 & 0.94 & \\
\hline & Season $\times$ Station & 2.55 & 7 & 0.36 & 0.17 & 0.99 & \\
\hline & Year $\times$ Season $\times$ Station & 1.78 & 7 & 0.25 & 0.12 & 0.99 & \\
\hline & Error & 67.38 & 32 & 2.11 & & & \\
\hline \multirow{8}{*}{$\begin{array}{l}\text { Chlorophyll a } \\
\left(\mu \mathrm{g} \mathrm{l}^{-1}\right)\end{array}$} & Year & 0.07 & 1 & 0.07 & 4.32 & 0.05 & \\
\hline & Season & 0.67 & 1 & 0.68 & 43.11 & $<0.001$ & \\
\hline & Station & 2.04 & 7 & 0.29 & 18.62 & $<0.001$ & \\
\hline & Year $\times$ Season & 0.07 & 1 & 0.07 & 4.79 & 0.04 & \\
\hline & Year $\times$ Station & 0.39 & 7 & 0.06 & 3.61 & 0.006 & \\
\hline & Season $\times$ Station & 0.43 & 7 & 0.06 & 3.93 & 0.003 & \\
\hline & Year $\times$ Season $\times$ Station & 0.28 & 7 & 0.04 & 2.53 & 0.034 & \multirow[t]{2}{*}{ Inconclusive } \\
\hline & Error & 0.5 & 32 & 0.02 & & & \\
\hline \multirow{8}{*}{$\begin{array}{l}\text { Zooplankton } \\
\text { biomass } \\
\left(\log _{10}\left[\mathrm{mg} \mathrm{m}^{-3}\right]\right)\end{array}$} & Year & 1.84 & 1 & 1.84 & 37.43 & $<0.001$ & \multirow{8}{*}{$\begin{array}{l}\text { A, B, C > F, G, H } \\
\text { Summer 1997-98 > All } \\
\text { other combinations }\end{array}$} \\
\hline & Season & 0.23 & 1 & 0.24 & 4.84 & 0.03 & \\
\hline & Station & 5.24 & 7 & 0.75 & 15.21 & $<0.001$ & \\
\hline & Year $\times$ Season & 0.66 & 1 & 0.66 & 13.41 & $<0.001$ & \\
\hline & Year $\times$ Station & 0.20 & 7 & 0.03 & 0.59 & 0.76 & \\
\hline & Season $\times$ Station & 0.31 & 7 & 0.04 & 0.9 & 0.52 & \\
\hline & Year $\times$ Season $\times$ Station & 0.24 & 7 & 0.03 & 0.7 & 0.68 & \\
\hline & Error & 1.82 & 37 & 0.05 & & & \\
\hline \multirow{8}{*}{$\begin{array}{l}\text { Zooplankton } \\
\text { abundance } \\
\left(\log _{10}\left[\text { no. } \mathrm{m}^{-3}\right]\right)\end{array}$} & Year & 0.45 & 1 & 0.45 & 6.43 & 0.02 & \multirow{8}{*}{$\begin{array}{l}1997-98>1998-99 \\
\text { Summer }>\text { Spring } \\
\text { A }>\text { F }\end{array}$} \\
\hline & Season & 0.61 & 1 & 0.61 & 8.81 & 0.005 & \\
\hline & Station & 3.37 & 7 & 0.48 & 6.87 & $<0.001$ & \\
\hline & Year $\times$ Season & 0.04 & 1 & 0.04 & 0.63 & 0.43 & \\
\hline & Year $\times$ Station & 0.11 & 7 & 0.02 & 0.23 & 0.97 & \\
\hline & Season $\times$ Station & 0.72 & 7 & 0.10 & 1.48 & 0.20 & \\
\hline & Year $\times$ Season $\times$ Station & 0.40 & 7 & 0.06 & 0.82 & 0.58 & \\
\hline & Error & 2.73 & 39 & 0.07 & & & \\
\hline \multirow{8}{*}{$\begin{array}{l}\text { Copepod } \\
\text { abundance } \\
\left(\log _{10}\left[\text { no. } \mathrm{m}^{-3}\right]\right)\end{array}$} & Year & 0.61 & 1 & 0.61 & 6.52 & 0.01 & \multirow[t]{8}{*}{$1997-98>1998-99$} \\
\hline & Season & 0.09 & 1 & 0.09 & 0.99 & 0.33 & \\
\hline & Station & 1.02 & 7 & 0.15 & 1.56 & 0.18 & \\
\hline & Year $\times$ Season & 0.26 & 1 & 0.26 & 2.84 & 0.1 & \\
\hline & Year $\times$ Station & 0.68 & 7 & 0.1 & 1.04 & 0.42 & \\
\hline & Season $\times$ Station & 0.96 & 7 & 0.14 & 1.48 & 0.20 & \\
\hline & Year $\times$ Season $\times$ Station & 0.26 & 7 & 0.04 & 0.39 & 0.9 & \\
\hline & Error & 3.62 & 39 & 0.09 & & & \\
\hline \multirow{8}{*}{$\begin{array}{l}\text { Pomacentrus } \\
\text { coelestis } \\
\left(\log _{10}\left[\text { no. } \mathrm{h}^{-1}\right]\right)\end{array}$} & Year & 1.27 & 1 & 1.27 & 9.74 & 0.003 & \multirow{8}{*}{$\begin{array}{l}1998-99>1997-98 \\
\text { February > December } \\
\text { C, D > E, B }\end{array}$} \\
\hline & Month & 1.5 & 3 & 0.50 & 3.82 & 0.01 & \\
\hline & Station & 7.98 & 3 & 2.66 & 20.36 & $<0.001$ & \\
\hline & Year $\times$ Month & 0.51 & 3 & 0.17 & 1.36 & 0.26 & \\
\hline & Year $\times$ Station & 0.51 & 3 & 0.17 & 1.30 & 0.28 & \\
\hline & Month $\times$ Station & 1.26 & 9 & 0.14 & 1.12 & 0.36 & \\
\hline & Year $\times$ Month $\times$ Station & 0.9 & 9 & 0.10 & 0.77 & 0.63 & \\
\hline & Error & & 39 & 0.13 & & & \\
\hline
\end{tabular}




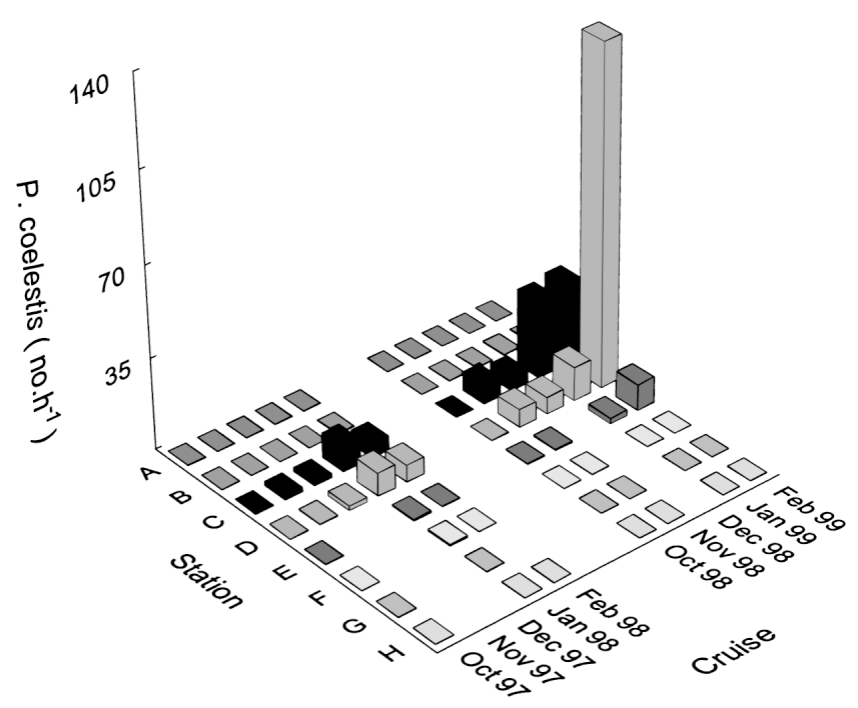

Fig. 3. Pomacentrus coelestis. Mean catches in light traps at stations (A to $\mathrm{H}$ ) on a cross-shelf transect in each of 2 summers (1997-98 and 1998-99) on the NW Shelf. Missing bars on the matrix show where no samples were collected, due to weather conditions

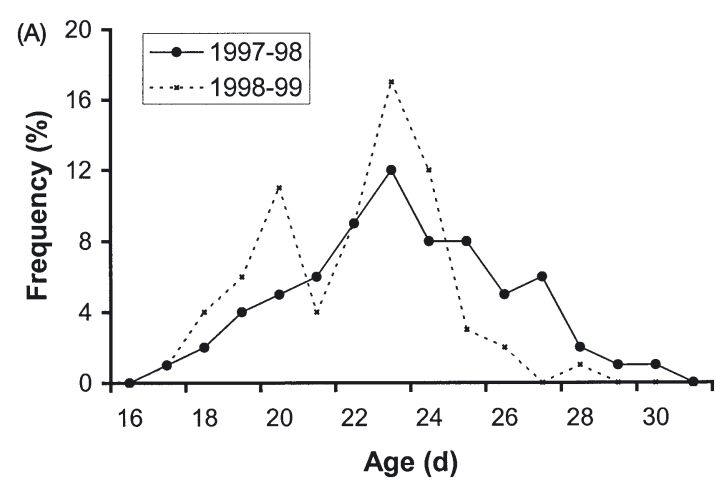

(B)

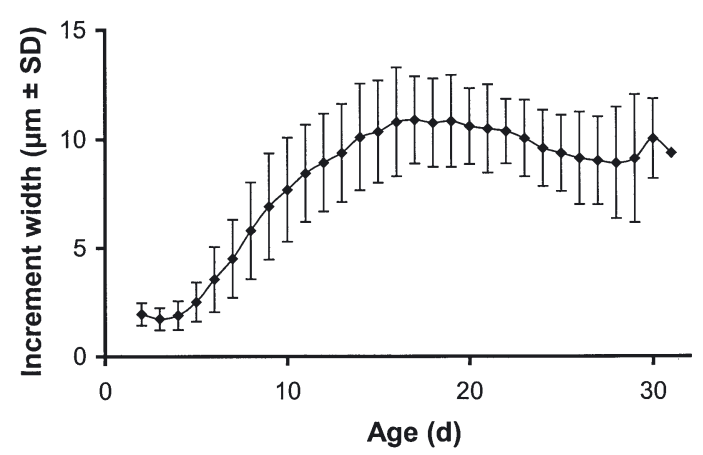

Fig. 4. Pomacentrus coelestis. Frequency distributions of (A) age and $(B)$ plots of average increment width $(n=150)$ versus age of fish collected by light traps in the 1997-98 and 1998-99 summers on the NW Shelf slightly older than those collected in the second summer (average age 23.2 vs $21.8 \mathrm{~d}$ respectively, KS test, $\mathrm{p}<0.01$, Fig. 4A).

Otolith analysis showed that Pomacentrus coelestis larvae grew slowly in the first 2 to $3 \mathrm{~d}$ after hatching (Fig. 4B). Growth rate then increased, peaking around 17 to $18 \mathrm{~d}$ and then gradually declining until capture by traps, which for the average fish occurred after $22 \mathrm{~d}$ $( \pm 2.61 \mathrm{SD})$ in the pelagic environment. Variance in the size-at-age data sets suggested that size differences established by $4 \mathrm{~d}$ after hatching persisted during pelagic life (Table 2). This was supported by significant correlations among daily otolith increments (Table 2). Fish that were fast-growing $4 \mathrm{~d}$ after hatching tended to maintain high growth rates during the remainder of planktonic life. Thus, growth patterns in this species were established within a few days of hatching and exhaustion of food supplies from the yolk sac, which for this species occurs 2 to $3 \mathrm{~d}$ after hatching (M. McCormick pers. comm.).

Repeated-measures MANOVAs of otolith radii data are summarised in Table 3A. The radius-at-age trajectories differed significantly among cruises and between summers, although the shapes of growth trajectories were similar in both summers, as there was no significant interaction between the factors of age, cruise and summer. On average, the sizes of otoliths of fish collected in the second summer were larger at age than those collected in the first summer from $8 \mathrm{~d}$ after hatching (Table 3B, Fig. 5). Univariate tests (Table 3B) showed that, with the exception of the 4 th and 5 th day after hatching, there were also significant differences in trajectories of otolith growth among cruises. In both years, fish collected in November were larger at hatching than those collected during other months (Fig. 6).

Results from the repeated-measures MANOVA of daily increment widths were similar to those of otolith radii. The analysis identified significant and consistent differences in increment widths among cruises and between summers (Table 4A,B). Univariate tests showed that, with the exception of the 7 th day after hatching, there were significant differences in increment widths both among cruises and between summers from $5 \mathrm{~d}$ after hatching (Table 4A,B). While trajectories of increment width diverged more quickly among months and were significantly greater in the 1998-99 summer than in the 1997-98 summer (Figs. $5 \& 6$ ), the shape of the curves were similar.

\section{Comparison of larval growth and environmental variables}

Water temperature had the highest partial correlation with larval growth rate (Table 5) and accounted 


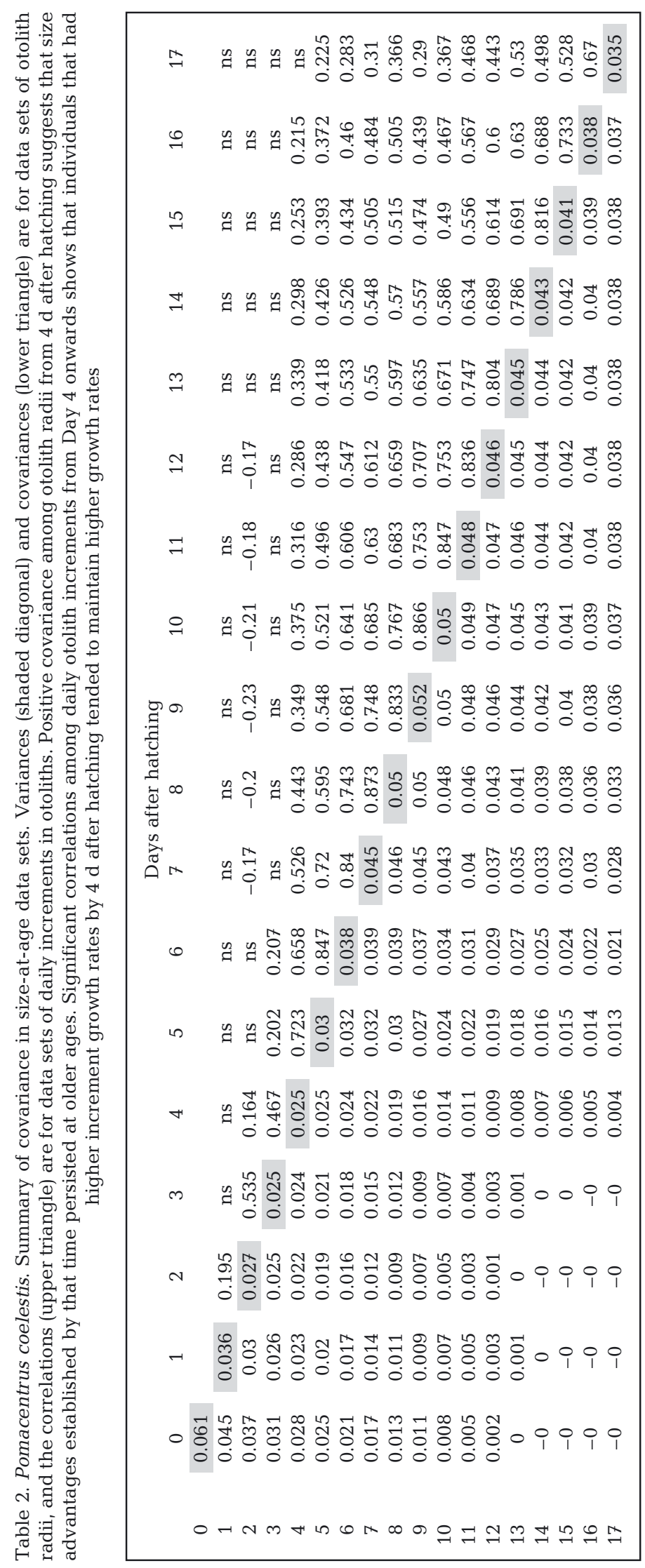

for approximately $30 \%$ of the variance in logtransformed daily increment widths. Chlorophyll $a$ and $\log$ of total zooplankton abundance, both of which had a negative relationship with growth rate, were the only other statistically significant parameters, but accounted for only 4.1 and $3.5 \%$ of the variance in growth, respectively.

\section{Larval growth and light trap catches}

When summed for each month, catches of Pomacentrus coelestis larvae in light traps were moderately correlated $\left(\mathrm{r}^{2}=0.57\right)$ with the average monthly growth rates (Fig. 7).

\section{DISCUSSION}

If food availability determines the growth of Pomacentrus coelestis larvae, we predicted that growth should have been fastest on the NW Shelf during summers characterised by upwelling events, when conditions favoured food production. Alternatively, if temperature was the factor driving larval growth, then rates should have been highest during the warm waters characteristic of the second summer. Our otolith analyses demonstrated that $P$. coelestis grew fastest during the summer of 1998-99, when water temperatures were relatively warm, implying that temperature, rather than food, was the primary environmental determinant of growth rate.

Models of population dynamics that involve density-dependent regulation of larval fish growth rates assume that the growth is directly related to food availability and that food is limiting in the plankton (Ware 1975, Shepherd \& Cushing 1980). Despite the prevalence of these concepts, few field studies have demonstrated significant relationships between food densities and growth rates, possibly because the effect of factors such as temperature and turbulence on larval growth has not been assessed (Heath 1992, Dower et al. 1997). Links between food availability and larval growth are thought to be particularly strong in tropical environments. Houde (1989) compared the growth, mortality rates and energetics of marine fish larvae in temperate and tropical regions and found that while tropical larvae grew relatively fast, growth did not appear to be more efficient at warmer temperatures. For this reason, he suggested that food availability was a principal factor regulating growth of tropical larvae, since their higher 
Table 3. Pomacentrus coelestis. (A) Summary of results of repeated-measures MANOVAs that compared otolith radii from 1 to $17 \mathrm{~d}$ after hatching of fish collected during cruises in November, December, January and February in each of the 1997-98 and 1998-99 summers. Data sets were transformed to natural log values prior to analysis. (B) Summary of results of $F$-tests of otolith radii from 0 to $17 \mathrm{~d}$ after hatching. Factors in the analysis were summer (1997-98 and 1998-99) and cruise (November, December, January, February). p-values are shown. Shaded values are non-significant at $\mathrm{p}<0.05$

\begin{tabular}{|c|c|c|c|c|c|}
\hline $\begin{array}{l}\text { (A) } \\
\text { Factor }\end{array}$ & Wilks Lambda & $F$ & Effect df & Error df & $\mathrm{p}$ \\
\hline Age & 0.005 & 1291.137 & 17 & 116 & $<0.001$ \\
\hline Age $\times$ Summer & 0.775 & 1.982 & 17 & 116 & 0.018 \\
\hline Age $\times$ Cruise & 0.383 & 2.585 & 51 & 346.156 & $<0.001$ \\
\hline Age $\times$ Summer $\times$ Cruise & 0.682 & 0.93 & 51 & 346.156 & 0.613 \\
\hline \multicolumn{6}{|l|}{ (B) } \\
\hline Day after hatching & Intercept & Summer & Cru & & $\begin{array}{l}\text { Summer } \times \\
\text { Cruise }\end{array}$ \\
\hline 0 & $<0.001$ & 0.225 & 0.0 & 01 & 0.147 \\
\hline 1 & $<0.001$ & 0.826 & 0.0 & 03 & 0.074 \\
\hline 2 & $<0.001$ & 0.705 & 0.0 & 06 & 0.129 \\
\hline 3 & $<0.001$ & 0.615 & 0.0 & & 0.105 \\
\hline 4 & $<0.001$ & 0.985 & 0.2 & 22 & 0.069 \\
\hline 5 & $<0.001$ & 0.298 & 0.3 & 65 & 0.06 \\
\hline 6 & $<0.001$ & 0.124 & 0.0 & 45 & 0.094 \\
\hline 7 & $<0.001$ & 0.079 & 0.0 & 01 & 0.133 \\
\hline 8 & $<0.001$ & 0.03 & $<0.0$ & & 0.296 \\
\hline 9 & $<0.001$ & 0.015 & $<0.0$ & & 0.394 \\
\hline 10 & $<0.001$ & 0.009 & $<0.0$ & & 0.382 \\
\hline 11 & $<0.001$ & 0.003 & $<0.0$ & & 0.327 \\
\hline 12 & $<0.001$ & 0.001 & $<0.0$ & & 0.389 \\
\hline 13 & $<0.001$ & 0.001 & $<0.0$ & & 0.502 \\
\hline 14 & $<0.001$ & 0.001 & $<0.0$ & & 0.539 \\
\hline 15 & $<0.001$ & $<0.001$ & $<0.0$ & & 0.624 \\
\hline 16 & $<0.001$ & $<0.001$ & $<0.0$ & & 0.613 \\
\hline 17 & $<0.001$ & $<0.001$ & $<0.0$ & & 0.63 \\
\hline
\end{tabular}

growth rates could only be maintained by high food consumption. Consequently, he predicted that tropical larvae might be more sensitive to starvation or low food availability than those in temperate waters, particularly at younger ages. Some support for Houde's (1987) theoretical work is provided by Bergenius et al. (2002). These authors identified a critical period (sensu Hjort 1914) during the first few weeks of larval life of a tropical surgeonfish Acanthurus chirugus, when growth rates were correlated with the numbers of larvae returning from the plankton to reef habitats. Growth at this time was not correlated with water temperature (M. Bergenius et al. unpubl.), implying that food availability was the principal factor driving growth rates.

Our results contradict this idea, since they suggest that growth rates of larval Pomacentrus coelestis were more closely correlated with temperature, rather than zooplankton abundance (food availability). Strong correlations between larval growth and water tempera- ture have also been recorded for another tropical pomacentrid, Stegastes partitus, by Wilson \& Meekan (2002); however, their study did not measure food availability and consequently, the relative influence of these factors could not be determined. Similar problems confound the interpretation of the results of a study by McCormick \& Molony (1995), who noted that up to $30 \%$ of the variation in growth among larval cohorts of the tropical goatfish Upeneus tragula could be accounted for by differences in water temperature.

Searcy \& Sponaugle (2000) proposed that differences in the relative importance of temperature and food to the growth of larval fishes in the tropics may reflect variability in early life history traits among species. They suggest that larvae of species with relatively short and invariant larval durations, such as Pomacentrus coelestis (mean = $22 \mathrm{~d}$, range 17 to $30 \mathrm{~d}$ on the NW Shelf) may be required to remain in areas where food is very abundant to ensure sufficient growth to a size suitable for settlement. In these habitats, growth may be largely driven by physical factors. In contrast, species with relatively long and variable larval durations, such as Thalassoma bifasciatum $($ mean $=51$, range 34 to 94 d, see Searcy \& Sponaugle 2000, their Table 4), may be more likely to encounter poor feeding conditions, so that growth is more likely to be influenced by food availability. This hypothesis ignores the possibility that relatively long larval durations might also result in larvae being subjected to greater temperature variation in the plankton, thus does not seem a plausible explanation of differences in the relative importance of temperature to larval growth among species.

Generally, growth rates and stage durations of larval fishes are most strongly correlated with water temperatures at large spatial scales (e.g. Campana \& Hurley 1989, Hovenkamp \& Witte 1991, Rilling \& Houde 1999, Bailey \& Heath 2001). Food availability appears more important at smaller scales, possibly because studies that sample at such scales can encompass only limited ranges of temperature variation (Bailey \& Heath 2001). However, this cannot explain the variation in environmental correlates of larval growth between our study and that of $\mathrm{M}$. Bergenius et al. (unpubl.), since both collected fish at 

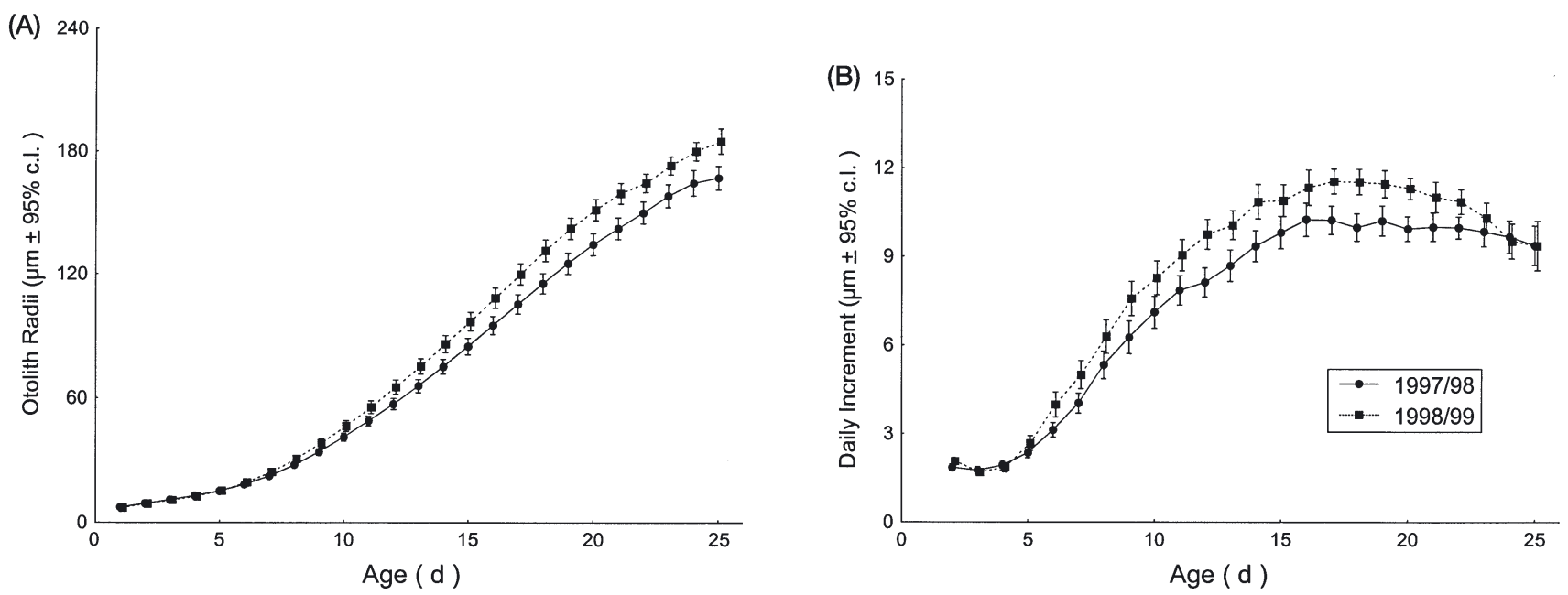

Fig. 5. Pomacentrus coelestis. Average (A) otolith radii and (B) increment widths of fish collected by light traps in the $1997-98$ and 1998-99 summers on the NW Shelf

similar spatial $(10 \mathrm{~s}$ of $\mathrm{km})$ and temporal scales. McCormick \& Molony (1995) and Searcy \& Sponaugle (2000) also obtained larvae at spatial scales comparable to those of the present study, although of the 2, the former only sampled for 2 mo.

It seems unlikely that the correlation between temperatures and growth of Pomacentrus coelestis larvae occurred because temperature ranges were close to the thermal limits of this species. Strong negative effects on development and survivorship of larval fish can occur when temperatures are elevated or depressed beyond these ranges (Blaxter 1992, Leach \& Houde 1999, Otterlei 1999). P. coelestis is, however, geographically widespread and occurs from cooler regions in southern Western Australia, 1000s of $\mathrm{km}$ to the south of our study site and throughout the tropics to the equator (Allen 1991, Hutchins 2001). The water temperatures recorded in our study are thus likely to be within the range encountered by larvae throughout much of the species distribution.
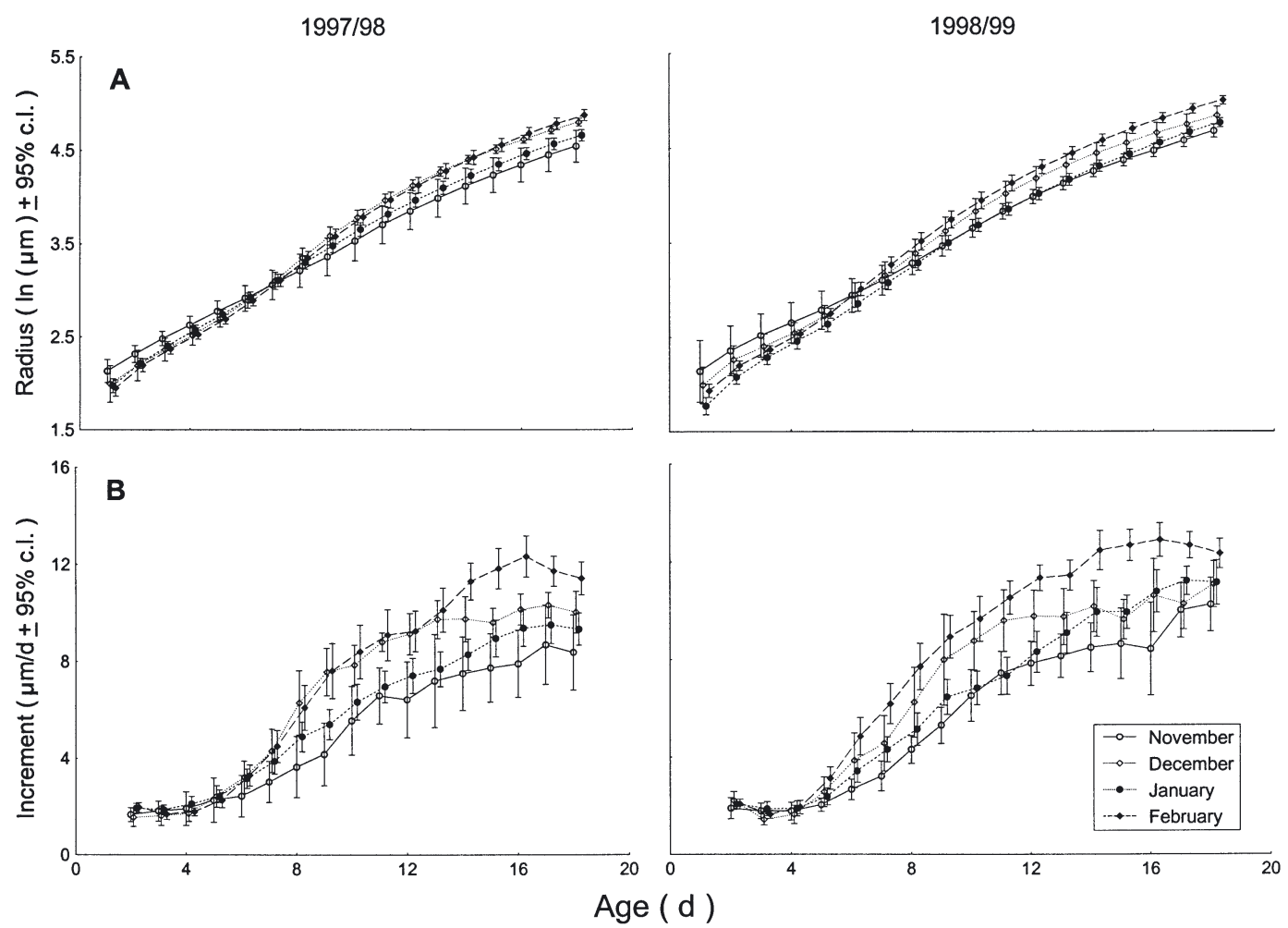

Fig. 6. Pomacentrus coelestis. Average (A) otolith radius and (B) increment width of fish collected by light traps in each month of the 1997-98 and 1998-99 summers on the NW Shelf 
Table 4. Pomacentrus coelestis. (A) Summary of results of a repeated-measures MANOVA that compared otolith increment widths from 1 to $17 \mathrm{~d}$ after hatching of fish collected during cruises in November, December, January and February in each of the 1997-98 and 1998-99 summers. (B) Summary of results of $F$-tests of otolith increment widths from 1 to $17 \mathrm{~d}$ after hatching. Factors in the analysis were summer (1997-98 and 1998-99) and cruise (November, December, January, February). p-values are shown. Shaded values are non-significant at $p<0.05$

\begin{tabular}{|lrrrrr|}
\hline Factor & & & & & \\
& Wilks Lambda & $F$ & Effect df & Error df & $p$ \\
\hline Age & 0.025 & 283.964 & 16 & 117 & $<0.001$ \\
Age $\times$ Summer & 0.767 & 2.221 & 16 & 117 & 0.008 \\
Age $\times$ Cruise & 0.349 & 3.088 & 48 & 348.781 & $<0.001$ \\
Age $\times$ Summer $\times$ Cruise & 0.719 & 0.853 & 48 & 348.781 & 0.745 \\
& & & & & \\
$(B)$ & & & & & \\
Day after hatching & Intercept & Summer & Cruise & Summer $\times$ \\
& & & & & Cruise \\
\hline 1 & & & & & \\
2 & $<0.001$ & 0.004 & 0.309 & 0.213 \\
3 & $<0.001$ & 0.545 & 0.049 & 0.916 \\
4 & $<0.001$ & 0.586 & 0.332 & 0.545 \\
5 & $<0.001$ & 0.276 & 0.111 & 0.029 \\
6 & $<0.001$ & 0.009 & $<0.001$ & 0.084 \\
7 & $<0.001$ & 0.033 & $<0.001$ & 0.113 \\
8 & $<0.001$ & 0.092 & $<0.001$ & 0.238 \\
9 & $<0.001$ & 0.011 & $<0.001$ & 0.864 \\
10 & $<0.001$ & 0.02 & $<0.001$ & 0.836 \\
11 & $<0.001$ & 0.012 & $<0.001$ & 0.515 \\
12 & $<0.001$ & $<0.001$ & $<0.001$ & 0.25 \\
13 & $<0.001$ & 0.008 & $<0.001$ & 0.485 \\
14 & $<0.001$ & 0.003 & $<0.001$ & 0.638 \\
15 & $<0.001$ & 0.036 & $<0.001$ & 0.763 \\
16 & $<0.001$ & 0.045 & $<0.001$ & 0.663 \\
17 & $<0.001$ & 0.001 & $<0.001$ & 0.207 \\
& $<0.001$ & $<0.001$ & $<0.001$ & 0.487 \\
\hline
\end{tabular}

tropical shorefishes. If copepods were not an important prey item for $P$. coelestis, the relatively high levels of primary production we documented in the first summer of sampling may have been transferred along trophic pathways that could not be accessed by the larvae of this species. Alternatively, the zooplankton communities that occurred in the first summer may not have included elements important to the larval diet. Dietary analyses of reef fish larvae on the NW Shelf are ongoing (A. Sampey et al. unpubl.).

If copepods and nauplii are indeed important prey, there is little evidence to suggest that larval Pomacentrus coelestis inhabit an environment where this food is superabundant. Plankton tows using a $64 \mu \mathrm{m}$ mesh net recorded average catches of 1 to 3 nauplii and copepodites per litre at stations on the NW Shelf (A. D. McKinnon unpubl.), densities that are lower than those found on shelves and bays in many temperate regions worldwide (MacKenzie et al. 1990). However, MacKenzie et al. (1990) caution that food densities recorded by net tows tend to be a poor predictor of larval feeding and that larvae may feed at maximal rates in relatively low densities due to their ability to exploit small scale patchiness

The suggestion that temperature was a principal determinant of growth rates of Pomacentrus coelestis assumes that zooplankton biomass provides an accurate measure of food availability for larvae. Copepods are the dominant taxon in zooplankton communities collected by net tows on the NW Shelf (A. D. McKinnon \& S. Duggan unpubl.). The various life-history stages of these organisms are the principal prey of fish larvae, at least in temperate regions (Heath 1992). The limited information available (see review by Leis 1991) suggests that they are also the major prey of the larvae of in zooplankton distributions and physical processes that enhance encounter rates between larvae and prey such as water turbulence. Additionally, experimental studies show that despite low standing stocks, rates of zooplankton productivity (as measured by copepod egg production) on the NW Shelf were often very high, although the timing of peaks in production tended to be sporadic and unpredictable at scales of hours to weeks (A. D. McKinnon unpubl.).

Our study adds further evidence to the suggestion that growth rates of larvae in the plankton are an

Table 5. Pomacentrus coelestis. Summary of partial correlation analysis that compared larval growth (log-transformed daily increment widths) with temperature, chlorophyll $a_{1} \log$ of zooplankton biomass, log abundance of total zooplankton and copepods

\begin{tabular}{|c|c|c|c|c|}
\hline Parameter & Beta & Partial correlation & $\mathrm{t}(130)$ & $\mathrm{p}$ \\
\hline Temperature $\left({ }^{\circ} \mathrm{C}\right)$ & 0.637 & 0.5484 & 7.4788 & $<0.001$ \\
\hline Chlorophyll a $\left(\mu \mathrm{g} \mathrm{l}^{-1}\right)$ & -0.238 & -0.2021 & -2.3531 & 0.02 \\
\hline Biomass $\left(\log _{10}\left[\mathrm{mg} \mathrm{m}^{-3}\right]\right)$ & 0.131 & 0.1009 & 1.1562 & 0.25 \\
\hline Zooplankton abundance $\left(\log _{10}\left[\right.\right.$ no. $\left.\left.\mathrm{m}^{-3}\right]\right)$ & -0.25 & -0.1879 & -2.1811 & 0.03 \\
\hline Copepod abundance $\left(\log _{10}\left[\right.\right.$ no. $\left.\left.^{-3}\right]\right)$ & 0.195 & 0.1630 & 1.8838 & 0.06 \\
\hline
\end{tabular}




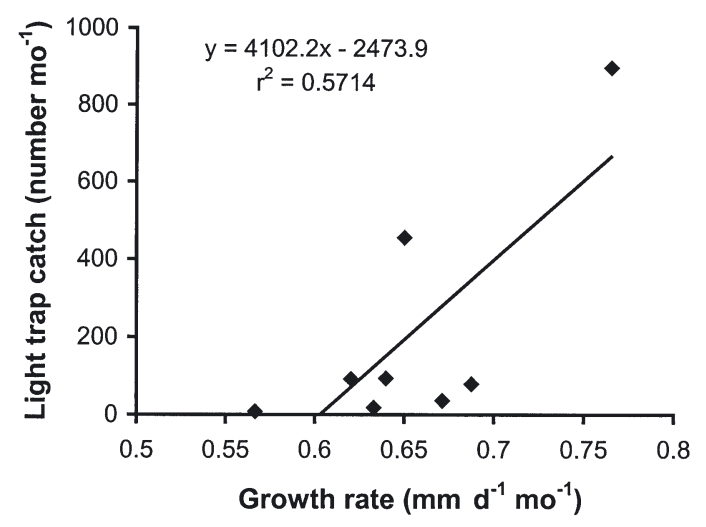

Fig. 7. Pomacentrus coelestis. Mean monthly larval growth rates versus catches in light traps during 2 summers on the NW Shelf

important determinant of the magnitude of settlement patterns of reef fishes in the tropics. We found that monthly variation in growth rate could account for over half the variation we found in catches of this species in light traps, although this result must be treated with caution, since the correlation between variables was strongly weighted by a single data point. Significant correlations between monthly larval growth and the supply of larvae to benthic habitats have also been recorded for a surgeonfish Acanthurus chirugus (Bergenius et al. 2002) and another pomacentrid Stegastes portitus (Wilson \& Meekan 2002) at the San Blas Archipelago in Caribbean Panama. In the latter case, correlations between monthly growth of larvae and light trap catches were very strong $\left(\mathrm{r}^{2}=0.89\right)$. The weaker relationship we recorded may be due to the limited duration of our light trap sampling where fish were collected by traps during a $10 \mathrm{~d}$ window around the new moon. Due to inclement weather conditions, light traps were rarely deployed on every night of a cruise. During breaks in sampling we may have missed peaks in larval supply, which is notoriously sporadic in both time and space (Doherty 1991). Wilson \& Meekan (2002) sampled for $19 \mathrm{~d}$ around the new moon, a period that is known to encompass the time when $95 \%$ of newly settling reef fishes arrive in reef habitats in the San Blas (Robertson 1992).

Fish that were growing fast in the first few days after hatching also tended to be individuals that grew quickly throughout larval life. Thus, the conditions for growth in the days immediately after hatching may be an important determinant of growth rates during later life and ultimately of the magnitude of larval supply. Bergenius et al (2002) also found that growth in the first weeks after hatching of Acanthurus chirugus was strongly correlated with the magnitude of catches on patch reefs. Such findings are consistent with the growth-predation hypothesis (Anderson 1988), which predicts that the influence of growth on survivorship should be greatest at young larval ages and sizes, since the mortality of larvae due to predation will decline as larvae grow. These and other studies (Searcy \& Sponaugle 2001, Wilson \& Meekan 2002) suggest that despite relatively fast growth rates, variability in growth of tropical reef fish larvae has an important influence on the outcome of mortality in the plankton and ultimately on the magnitude of larval supply to reef environments. The present study shows that for Pomacentrus coelestis, variability in larval growth may be largely determined by water temperatures in the pelagic environment.

Acknowledgements. We are grateful for the aid of the numerous volunteers, staff and crew of the RV 'Lady Basten' that assisted with fieldwork. In particular we thank A. Halford and L. Vigliola for their input, both in the field and laboratory. J. Leis, S. Sponagule and D. Ponton provided useful comments on drafts of the manuscript.

\section{LITERATURE CITED}

Allen GR (1991) Damselfishes of the world. Mergus Publishers, Melle

Anderson JT (1988) A review of size dependent survival during pre-recruit stages of fishes in relation to recruitment. J Northwest Atl Fish Sci 8:55-66

Bailey KM, Houde ED (1989) Predation on eggs and larvae of marine fishes and the recruitment problem. Adv Mar Biol 25:1-83

Bailey MC, Heath MR (2001) Spatial variability in the growth rate of blue whiting (Micromesistius poutassou) larvae at the shelf edge west of the UK. Fish Res 50:73-87

Bergenius MAJ, Meekan MG, Robertson DR, McCormick MI (2002) Larval growth predicts the recruitment success of a coral reef fish. Oecologia 131:521-525

Blaxter JHS (1992) The effect of temperature on larval fishes. Neth J Zool 42:336-357

Campana SE, Hurley CF (1989) An age- and temperaturemediated growth model for cod (Gadus morhua) and haddock (Melanogrammus aeglefinus) larvae in the Gulf of Maine. Can J Fish Aquat Sci 46:603-613

Chambers RC, Miller TJ (1994) Evaluating fish growth by means of otolith increment analysis: spectral properties of individual-level longitudinal data. In: Secor DH, Dean JM, Campana SE (eds) Recent developments in fish otolith research. University of South Carolina Press, Columbia, p 155-175

Doherty PJ (1987) Light traps: selective but useful devices for quantifying the distributions and abundances of larval fishes. Bull Mar Sci 41:423-431

Doherty PJ (1991) Spatial and temporal patterns in recruitment. In: Sale PF (ed) The ecology of fishes on coral reefs. Academic Press, San Diego, p 261-293

Dower JF, Miller TJ, Leggett WC (1997) The role of microscale turbulence in the feeding ecology of larval fish. Adv Mar Biol 31:169-220

Campana SE, Neilson JD (1985) Microstructure of fish otoliths. Can J Fish Aquat Sci 42:1014-1032

Cushing DH, Horwood JW (1994) The growth and death of fish larvae. J Plankton Res 16:291-300 
Heath MR (1992) Field investigations of the early life stages of marine fish. Adv Mar Biol 28:1-174

Hjort J (1914) Fluctuations in the great fisheries of northern Europe. Rap P-v Reun Cons Int Explor Mer 20:1-228

Holloway PE, Humphries SE, Atkinson M, Imberger J (1985) Mechanisms for nitrogen supply to the Australian North West Shelf. Aust J Mar Freshw Res 36:753-764

Houde ED (1987) Fish early life dynamics and recruitment variability. Am Fish Soc Symp 2:17-29

Houde ED (1989) Comparative growth, mortality, and energetics of marine fish larvae: temperature and implied latitudinal effects. Fish Bull 87:471-495

Houde ED, Zastrow CE (1993) Ecosystem- and taxon-specific dynamic and energetics properties of larval fish assemblages. Bull Mar Sci 53:290-335

Hovenkamp F, Witte JIJ (1991) Growth, otolith growth and RNA/DNA ratios of larval plaice Pleuronectes platessa in the North Sea 1987 to 1989. Mar Ecol Prog Ser 70:105-116

Hutchins JB (2001) Biodiversity of shallow reef fish assemblages in Western Australia using a rapid censusing technique. Rec West Aust Mus 20:247-270

Leach SD, Houde ED (1999) Effect of environmental factors on survival, growth and production of American shad larvae. J Fish Bio 54:767-786

Leis JM (1991) The pelagic stage of reef fishes: the larval biology of coral reef fishes. In: Sale PF (ed) The ecology of fishes on coral reefs. Academic Press, San Diego, p 183-230

MacKenzie BR, Leggett WC, Peters RH (1990) Estimating larval fish ingestion rates: can laboratory values be reliably extrapolated to the wild? Mar Ecol Prog Ser 67: 209-225

McCormick MI, Molony BW (1995) Influence of water temperature during the larval stage on size, age and body condition of a tropical reef fish at settlement. Mar Ecol Prog Ser 118:59-68

McKinnon AD, Duggan S (2001) Summer egg production rates of paracalanid copepods in subtropical waters adjacent to Australia's North West Cape. Hydrobiologia 453/454:121-131

Meekan MG, Milicich MJ, Doherty PJ (1993) Larval production drives temporal patterns of larval supply and recruitment of a coral reef damselfish. Mar Ecol Prog Ser 93: $217-225$

Meekan MG, Wilson SG, Halford A, Retzel A (2001) A comparison of catches of fishes and invertebrates by two light

Editorial responsibility: Otto Kinne (Editor), Oldendorf/Luhe, Germany trap designs, in tropical NW Australia. Mar Biol 139: 373-381

Otterlei E, Nyhammer G, Folkvord A, Stefansson SO (1999) Temperature- and size-dependent growth of larval and early juvenile Atlantic cod (Gadus morhua): a comparative study of Norwegian coastal cod and northeast Arctic cod. Can J Fish Aquat Sci 56:2099-2111

Rilling GC, Houde ED (1999) Regional and temporal variability in growth and mortality of bay anchovy, Anchoa mitchilli, larvae in Chesapeake Bay. Fish Bull 97:555-569

Robertson DR (1992) Patterns of lunar settlement and early recruitment in Caribbean reef fishes at Panama. Mar Biol 114:527-537

Runge JA (1998) Should we expect a relationship between primary production and fisheries? The role of copepod dynamics as a filter of trophic variability. Hydrobiologia 167/168:61-71

Searcy SP, Sponaugle S (2000) Variable larval growth in a coral reef fish. Mar Ecol Prog Ser 206:213-226

Shepherd JG, Cushing DH (1980) A mechanism for density dependent survival of larval fish as the basis of a stock recruitment relationship. J Cons Inst Explor Mer 39: 160-167

Thorrold SR, Milicich MJ (1990) Comparison of larval duration and pre- and post-settlement growth in two species of damselfish, Chromis atripectoralis and Pomacentrus coelestis (Pisces: Pomacentridae), from the Great Barrier Reef. Mar Biol 105:375-384

Ware DM (1975) Relation between egg size, growth and natural mortality of larval fish. Can J Fish Aquat Sci 32: $2503-2512$

Wellington GM, Victor BC (1989) Planktonic larval duration of one hundred species of Pacific and Atlantic damselfishes (Pomacentridae). Mar Biol 101:557-567

Wellington GM, Victor BC (1992) Regional differences in duration of the planktonic larval stage of reef fishes in the eastern Pacific Ocean. Mar Biol 113:491-498

Weiner (1971) Statistical principles in experimental design, 2nd edn. McGraw-Hill, New York

Wilson DT, Meekan MG (2002) Growth related advantages for survival to the point of replenishment in the coral reef fish Stegastes partitus (Pomacentridae). Mar Ecol Prog Ser 231:247-260

Zar JH (1984) Biostatistical analysis, 2nd edn. Prentice Hall, Englewood Cliffs, NJ

Submitted: July 24, 2002; Accepted: February 18, 2003

Proofs received from author(s): June 18, 2003 